Research Article

\title{
Macro-nutrient intake of reproductive age group women: findings of a community based study from rural Varanasi
}

\author{
Zoobi Khanam*, Hari Shankar, C. P. Mishra
}

Department of Community Medicine, Institute of Medical Sciences, Banaras Hindu University, Varanasi, UP, India

Received: 29 December 2015

Accepted: 23 January 2016

*Correspondence:

Dr. Zoobi Khanam,

E-mail: zoobi.bhu@gmail.com

Copyright: (C) the author(s), publisher and licensee Medip Academy. This is an open-access article distributed under the terms of the Creative Commons Attribution Non-Commercial License, which permits unrestricted non-commercial use, distribution, and reproduction in any medium, provided the original work is properly cited.

\begin{abstract}
Background: Indian rural women are in a disadvantaged position on nutritional scale due to variety of reasons including inadequate consumption of macronutrients. With this background, a comprehensive dietary assessment of macro-nutrient (energy, protein, and fat) intake of rural women of reproductive age group was contemplated with the objectives: (a) to assess macro nutrients (energy, protein, and fat) intake of study subjects, and (b) to pin point the correlates of their macro nutrients intake.

Methods: This study was conducted in a Community Development Block of Varanasi district of Uttar Pradesh adopting a community based cross sectional study design. Non pregnant women of reproductive age group (15-49 years) were considered as subjects of this study and the required sample size (610) was selected by adopting multi stage random sampling procedure. Socio-demographic characteristics were obtained by interview technique and dietary intake was assessed by 24 hour oral recall questionnaire method.

Results: The average energy, protein and fat intakes were $1657.81 \pm 461.91 \mathrm{Kcal} / \mathrm{day}, 45.05 \pm 18.79 \mathrm{gm} / \mathrm{day}$, and 37.52 $\pm 31.16 \mathrm{gm} /$ day, respectively. With respect to Nutrient Adequacy Ratio of these macro-nutrients, the values were $84.4 \%, 81.82 \%$ and $55.54 \%$ of respective estimated RDAs. Socioeconomic status (SES) exerted a significant $(\mathrm{p}<0.05)$ influence in all these three macro-nutrient consumption. Along with SES, age of study subjects was also found to be significantly $(p<0.05)$ associated with protein intake and castes of study subjects were found to be significantly $(\mathrm{p}<0.05)$ associated with daily fat intake as well.

Conclusions: Well developed nutrition education programmes for women are needed to ensure adequate consumption of macro-nutrients.
\end{abstract}

Keywords: Macro-nutrient intake, Rural women, Reproductive age group

\section{INTRODUCTION}

Nutrition is directly linked to the human resource development, productivity and prosperity of a country. It is the focal point of health and well being. Health status of any individual or a community is directly indicated by the nutritional status of the particular individual or community. ${ }^{1}$ Over 225 million Indians remain chronically undernourished. ${ }^{2}$ India's malnutrition and Chronic Energy Deficiency (CED) figures are not coming down despite a number of government programmes. As per NFHS-2
$(1998-99)^{3}$ and NFHS-3(2005-06 $)^{4}$, there have been marginal changes in child malnutrition and CED in women over a period of seven years. There are about 800 million people undernourished in the world. Most of them live in developing country, about $30 \%$ each in southern and eastern Asia, 25\% in sub- Saharan Africa, and $8 \%$ in Latin America and the other Caribbean. ${ }^{5}$

Chronic Energy Deficiency results when the body needs for energy fuels (carbohydrate, fat, protein) cannot be met by the diet. It includes a wide spectrum of clinical 
manifestations conditioned by relative intensity of energy deficit, the severity and duration of deficiencies, the age of the host, the cost of the deficiency, and the association with other nutritional or infectious diseases. Its severity ranges from weight loss or growth retardation to distinct clinical syndromes, frequently associated with minerals and vitamins.

Women play a vital role in providing food and nutrition for their families through their roles as food producers, processors, traders and income earners. Insufficient food supplies are a major cause of malnutrition in technically under developed countries. Small farm agriculture in these areas frequently does not yield enough food to meet the full needs of the family, much less the surplus for distribution, and most imported foods are too expensive for the majority of the families. There are many foods that are readily available in tropical areas that have relatively low concentration of essential nutrients, the staple foods in these areas do not contain sufficient protein to meet requirements and also quality of these foods is generally poor. Some species of corn may have a protein concentration of $10 \%$, and their biological value is less than $50 \%$. Even in legumes the percentage of protein does not usually exceed $25 \%$, and after the correction is made for the quality, this is reduced to less than $15 \%$ of utilizable protein. Because of dilution with water, cooking lowers further the utilizable protein concentration. Animal foods are the best protein sources, but they tend to be expensive, not always available, or prohibited by religious practices.

Seventy four percent of Indian population lives in rural areas. Inter and intra state disparity is visible across the country in term of health, nutrition, fertility, and educational status. Thus urban areas are always ahead of rural areas in terms of different aspects of development. ${ }^{6}$ Therefore; nutritional status of Indian women is also very poor. In 2005-06, 34.2\% women of reproductive age group of Uttar Pradesh were found to be chronically malnourished whereas this was $37.2 \%$ for those residing in rural areas. ${ }^{4}$ With this background, in present study a comprehensive dietary assessment of macro-nutrient (energy, protein, and fat) intake of rural women of reproductive age group was contemplated with the following specific objectives:

a. To assess macro nutrients (energy, protein, and fat) intake of study subjects and their adequacy.

b. To pin point the correlates of macro nutrients intake.

\section{METHODS}

This study was conducted in rural areas of Varanasi. Varanasi is often called cultural capital of India. The district lies in the eastern part of Uttar Pradesh state. Total population of district is 3682194 of which $56.57 \%$ is rural. The literacy rate of district is $77.05 \%$ (male $85.12 \%$ female $68.20 \%$ ) and the overall sex ratio for the district is $909 .^{7}$ A community based cross sectional design was adopted and women of reproductive age group (1549 years) were considered as sample for this study. Pregnant and seriously ill women were excluded. Computation of required sample size of 576 was based on the assumption that prevalence of CED in the rural reproductive age group women is around $40 \%$ and permissible level of error as $10 \%$ of the prevalence rate. Taking an additional sample of 5\% for drop outs required sample size became 605.04 which were rounded to 610 . The required sample was selected by adopting multi stage sampling. Following stages were involved in the selection of study subjects:

\section{Stage 1:}

In the first stage, one commisionary of Uttar Pradesh state (comprising of 7 districts) was selected randomly. From the selected commisionary, one district (viz. Varanasi) was selected randomly.

\section{Stage 2:}

One Community Development (CD) block (i.e. Chiraigaon) was selected from eight CD blocks of Varanasi district by simple random sampling method.

\section{Stage 3:}

In this stage, 5 villages out of 84 revenue villages were selected further by systematic random sampling. The selected villages were Bariyasanpur, Dubkiyan, Narayanpur, Tilmapur, and Umraha.

\section{Stage 4:}

In the selected villages subjects were selected by adopting probability proportion to size (PPS). In order to get required study subjects (610), systemic random sampling (every seventh household) was done.

\section{Stage 5:}

From each household one study subject was selected for study. ${ }^{8}$ In case there were more than one eligible subjects in a household, one subject was selected by lottery method.

The study had prior approval of the academic and governing bodies of Banaras Hindu University, Varanasi, India and prior consent was taken from the study subjects for participation in this study.

The present investigation is a kind of field study in which primary tool used was a predesigned and pre-tested interview schedule for recording of family as well as information pertaining to the individuals considered for the study. Each study subject was subjected to dietary assessment. The dietary assessment of study subjects was done by using 24 hour dietary recall oral questionnaire method. Macro nutrient intake of each subject was 
computed in terms of daily intake of energy, protein and fat. Standard utensils (e.g. bowls for measuring cooked rice, dal, curd, vegetables, milk etc.; spoon for measuring oil, sugar etc.) were used for measuring the approximate intake of different food items. Dilution factor of liquid food such as dal was also noted. Diet survey was not conducted on the day after any festival or any other special occasion. Data pertaining to $5 \%$ of samples were cross checked by the other researcher for quality assurance.

Data thus collected was entered in personal computer. Statistical Package for Social Sciences (SPSS 16th version) and Microsoft Excel (2007 version) were used for analysis. Intake in terms of energy, protein, and fat were computed as per Nutritive Value of Indian Foods. ${ }^{9}$ Nutrient Adequacy Ratio (NAR) was calculated by comparing with corresponding Recommended Dietary Allowances (RDA) recommended by ICMR, 2010. ${ }^{9}$ In order to identify absolute contribution of influencing factors logistic regression was applied. The other statistics incorporated in this study included Mean $\pm \mathrm{SD}$, Confidence Interval (CI) and ANOVA with 'post hoc' test.

\section{RESULTS}

Macro nutrient intake of study subjects is given in Table 1. Average energy, protein and fat intakes were $1657.81 \pm 461.91 \mathrm{Kcal} /$ day, $45.05 \pm 18.79 \mathrm{gm} /$ day, and $37.52 \pm 31.16 \mathrm{gm} /$ day, respectively. With respect to NAR of these macro-nutrients, the values were $84.4 \%, 81.82 \%$ and $55.54 \%$ of respective estimated RDA.

Table 1: Macro nutrient intake of study subjects.

\begin{tabular}{|lllll|}
$\begin{array}{l}\text { Macro } \\
\text { Nutrients }\end{array}$ & RDA* & $\begin{array}{l}\text { Mean } \\
(\text { SD })\end{array}$ & $\begin{array}{l}\text { CI } \\
(\mathbf{9 5} \%)\end{array}$ & $\begin{array}{l}\text { NAR } \\
(\%)\end{array}$ \\
\hline $\begin{array}{l}\text { Energy } \\
(\text { Kcal/d) }\end{array}$ & $\begin{array}{l}\text { S-1900 } \\
\text { M-2230 }\end{array}$ & $\begin{array}{l}1657.81 \\
( \pm 461.91)\end{array}$ & $\begin{array}{l}1621.15- \\
1694.47\end{array}$ & 84.40 \\
\hline $\begin{array}{l}\text { Protein } \\
\text { (g/d) }\end{array}$ & 55 & $\begin{array}{l}45.05 \\
( \pm 18.79)\end{array}$ & $\begin{array}{l}43.55- \\
46.54\end{array}$ & 81.82 \\
\hline & S-20 & 37.52 & $35.04-$ & 55.54 \\
Fat (g/d) & M-25 & $( \pm 31.16)$ & 40.00 & \\
\hline & H-30 & & for & \\
\hline
\end{tabular}

* Recommended Dietary Allowances for Indian women (2010). ${ }^{\text {? }}$

Distribution of study subjects according to NAR of energy (Kcal/day) with respect to RDA is given in Figure 1. In case of $14.6 \%$ subjects daily calorie consumption was $<50 \%$ of RDA whereas $37.4 \%$ subjects had calorie consumption $\geq$ RDA.

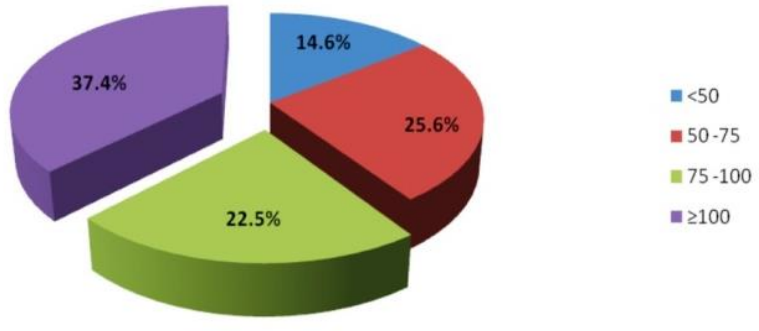

Figure 1: Distribution of study subjects according to Nutrient Adequacy Ratio (NAR) of energy (Kcal) w.r.t. RDA.

In all $257(42.13 \%)$ subjects had protein intake $\geq 80 \%$ of RDA. Protein consumption was $<50 \%$ of RDA in $12.5 \%$ subjects (Table 2). In the present study, study population was heterogeneous in terms of consumption of fat. One hundred forty six $(23.93 \%)$ had percentage intake of fat with respect to RDA $<50 \%$ whereas $58.7 \%$ subjects had fat consumption $\geq$ RDA (Figure 2).

Table 2: Distribution of study subjects according to NAR of Protein w.r.t. RDA.

\begin{tabular}{|lll|}
\hline NAR & $\mathbf{N}$ & Percent \\
\hline$<50$ & 76 & 12.5 \\
\hline $50-59.99$ & 133 & 21.8 \\
\hline $60-69.99$ & 76 & 12.5 \\
\hline $70-79.99$ & 68 & 11.1 \\
\hline $80-89.99$ & 38 & 6.2 \\
\hline $90-99.99$ & 28 & 4.6 \\
\hline$\geq 100$ & 191 & 31.3 \\
\hline Total & 610 & 100.0 \\
\hline
\end{tabular}

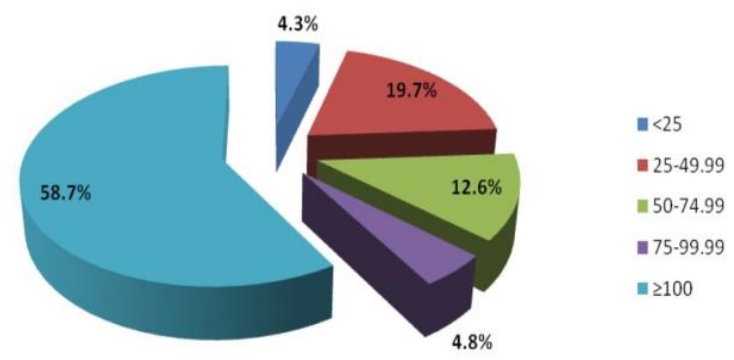

Figure 2: Distribution of study subjects according to Nutrient Adequacy Ratio (NAR) of fat (visible) w.r.t. RDA.

Calorie intake of study subjects according to their sociodemographic characteristics is given in Table 3. None of the variables (viz. Age, religion, caste, type of family, marital status, educational status, primary occupation of subjects and maximum education and main occupation of the family) except socio-economic status (SES) were significantly associated with energy intake. 
Table 3: Energy intake (Kcal/day) of study subjects according to their socio-demographic characteristics.

\begin{tabular}{|c|c|c|c|c|c|}
\hline Sr. no. & Variables & $\mathbf{N}$ & Mean (SD) & $\mathbf{F}$ & $\mathbf{P}$ \\
\hline 1 & Age of the subjects ( in ye & & & & \\
\hline & $15-24$ & 219 & $1685.82( \pm 445.01)$ & \multirow{4}{*}{1.440} & \multirow{4}{*}{0.230} \\
\hline & $25-34$ & 196 & $1628.11( \pm 471.27)$ & & \\
\hline & $35-44$ & 151 & $1626.90( \pm 484.14)$ & & \\
\hline & $\geq 45$ & 44 & $1756.77( \pm 414.17)$ & & \\
\hline \multirow[t]{3}{*}{2} & Religion & & & & \\
\hline & Hindu & 566 & $1655.62( \pm 460.77)$ & \multirow{2}{*}{0.176} & \multirow{2}{*}{0.675} \\
\hline & Muslim & 44 & $1685.94( \pm 480.87)$ & & \\
\hline \multirow[t]{4}{*}{3} & Caste & & & & \\
\hline & SC \& ST & 191 & $1651.21( \pm 467.56)$ & \multirow{3}{*}{0.130} & \multirow{3}{*}{0.878} \\
\hline & OBC & 285 & $1653.84( \pm 471.77)$ & & \\
\hline & Others & 134 & $1675.66( \pm 434.72)$ & & \\
\hline \multirow[t]{4}{*}{4} & Type of family & & & & \\
\hline & Nuclear & 320 & $1661.42( \pm 477.39)$ & \multirow{3}{*}{0.021} & \multirow{3}{*}{0.979} \\
\hline & Joint & 260 & $1654.09( \pm 442.45)$ & & \\
\hline & Three generation family & 30 & $1651.50( \pm 474.24)$ & & \\
\hline \multirow[t]{4}{*}{5} & Marital status of subjects & & & & \\
\hline & Unmarried & 159 & $1666.27( \pm 456.47)$ & \multirow{3}{*}{0.055} & \multirow{3}{*}{0.947} \\
\hline & Married & 436 & $1654.05( \pm 466.87)$ & & \\
\hline & Widow \& separated & 15 & $1677.49( \pm 393.88)$ & & \\
\hline \multirow[t]{7}{*}{6} & Educational status of subj & & & & \\
\hline & Illiterate & 206 & $1649.23( \pm 494.45)$ & \multirow{6}{*}{0.526} & \multirow{6}{*}{0.757} \\
\hline & Primary & 70 & $1712.09( \pm 418.34)$ & & \\
\hline & Middle & 90 & $1639.91( \pm 463.93)$ & & \\
\hline & H. School & 86 & $1689.64( \pm 442.89)$ & & \\
\hline & Intermediate & 93 & $1664.66( \pm 420.90)$ & & \\
\hline & Graduate or above & 65 & $1599.43( \pm 484.93)$ & & \\
\hline \multirow[t]{7}{*}{7} & Primary occupation of sul & & & & \\
\hline & Housewife & 386 & $1648.94( \pm 470.46)$ & \multirow{6}{*}{0.348} & \\
\hline & Domestic worker & 36 & $1603.36( \pm 479.10)$ & & \\
\hline & Agriculture labor & 19 & $1672.01( \pm 476.95)$ & & 0884 \\
\hline & Service & 11 & $1618.57( \pm 350.96)$ & & 0.884 \\
\hline & Student & 130 & $1698.18( \pm 433.84)$ & & \\
\hline & Skilled worker & 28 & $1668.51( \pm 49.29)$ & & \\
\hline 8 & Socio-economic status & & & & \\
\hline & Upper class & 33 & $1567.21( \pm 479.08)$ & & \\
\hline & Upper middle class & 56 & $1613.26( \pm 406.88)$ & & \\
\hline & Middle class & 100 & $1765.57( \pm 442.72)$ & 6.287 & 0.000 \\
\hline & Lower middle class & 199 & $1742.58( \pm 427.16)$ & & \\
\hline & Lower class & 222 & $1557.10( \pm 488.63)$ & & \\
\hline 9 & Maximum education in th & & & & \\
\hline & Illiterate & 19 & $1472.13( \pm 520.62)$ & & \\
\hline & Upto primary & 68 & $1716.37( \pm 461.34)$ & & \\
\hline & Upto junior high school & 82 & $1587.73( \pm 532.80)$ & & \\
\hline & Upto high school & 120 & $1714.64( \pm 442.54)$ & 1.825 & 0.092 \\
\hline & Upto intermediate & 132 & $1704.19( \pm 433.19)$ & & \\
\hline & Upto graduation & 126 & $1628.24( \pm 426.33)$ & & \\
\hline & Above graduation & 63 & $1595.54( \pm 489.85)$ & & \\
\hline 10 & Main occupation of head & amily & & & \\
\hline & Farmer & 78 & $1587.96( \pm 471.30)$ & & \\
\hline & Labor & 228 & $1684.89( \pm 469.15)$ & & \\
\hline & Service & 137 & $1611.53( \pm 497.80)$ & 1.244 & 0.291 \\
\hline & Business & 96 & $1702.95( \pm 381.16)$ & & \\
\hline & Skilled worker & 71 & $1675.87( \pm 452.056)$ & & \\
\hline
\end{tabular}


Table 4: Protein intake (gm/day) of study subjects according to their Socio-demographic characteristics.

\begin{tabular}{|c|c|c|c|c|c|}
\hline Sr. no. & Variables & $\mathbf{N}$ & Mean (SD) & $\mathbf{F}$ & $\mathbf{P}$ \\
\hline 1 & Age of the subjects ( in $y$ & & & & \\
\hline & $15-24$ & 245 & $46.1( \pm 17.53)$ & \multirow{4}{*}{3.137} & \multirow{4}{*}{0.025} \\
\hline & $25-34$ & 170 & $41.4( \pm 15.93)$ & & \\
\hline & $35-44$ & 151 & $47.1( \pm 23.33)$ & & \\
\hline & $\geq 45$ & 44 & $46.42( \pm 16.91)$ & & \\
\hline \multirow[t]{3}{*}{2} & Religion & & & & \\
\hline & Hindu & 566 & $45.04( \pm 18.83)$ & \multirow{2}{*}{0.002} & \multirow{2}{*}{0.966} \\
\hline & Muslim & 44 & $45.16( \pm 18.51)$ & & \\
\hline \multirow[t]{4}{*}{3} & Caste & & & & \\
\hline & SC \& ST & 191 & $42.94( \pm 22.55)$ & \multirow{3}{*}{1.755} & \multirow{3}{*}{0.174} \\
\hline & $\mathrm{OBC}$ & 285 & $46.06( \pm 17.25)$ & & \\
\hline & Others & 134 & $45.89( \pm 15.68)$ & & \\
\hline \multirow[t]{4}{*}{4} & Type of family & & & & \\
\hline & Nuclear & 320 & $45.83( \pm 18.06)$ & \multirow{3}{*}{1.234} & \multirow{3}{*}{0.292} \\
\hline & Joint & 260 & $43.75( \pm 19.94)$ & & \\
\hline & Three generation family & 30 & $47.86( \pm 15.69)$ & & \\
\hline \multirow[t]{4}{*}{5} & Marital status of subjects & & & & \\
\hline & Unmarried & 159 & $47.26( \pm 17.60)$ & \multirow{3}{*}{1.517} & \multirow{3}{*}{0.220} \\
\hline & Married & 436 & $44.23( \pm 19.29)$ & & \\
\hline & Widow \& separated & 15 & $45.27( \pm 15.13)$ & & \\
\hline \multirow[t]{8}{*}{6} & Educational status of sub & & & \multirow{8}{*}{0.257} & \\
\hline & Illiterate & 206 & $45.76( \pm 22.52)$ & & \multirow{7}{*}{0.956} \\
\hline & Primary & 70 & $44.53( \pm 17.61)$ & & \\
\hline & Middle & 90 & $43.48( \pm 16.58)$ & & \\
\hline & H. School & 86 & $46.29( \pm 17.67)$ & & \\
\hline & Intermediate & 93 & $44.37( \pm 16.34)$ & & \\
\hline & Graduate & 50 & $44.49( \pm 14.50)$ & & \\
\hline & PG or above & 15 & $45.91( \pm 15.36)$ & & \\
\hline \multirow[t]{7}{*}{7} & Primary occupation of su & & & & \\
\hline & Housewife & 386 & $44.39( \pm 19.46)$ & & \\
\hline & Domestic worker & 36 & $40.59( \pm 16.84)$ & & \\
\hline & Agriculture labor & 19 & $46.18( \pm 17.51)$ & & \\
\hline & Service & 11 & $42.72( \pm 14.96)$ & 1.262 & 0.279 \\
\hline & Student & 130 & $48.14( \pm 17.67)$ & & \\
\hline & Skilled worker & 28 & $45.63( \pm 18.39)$ & & \\
\hline 8 & Socio-economic status & & & & \\
\hline & Upper class & 33 & $35.72( \pm 4.06)$ & & \\
\hline & Upper middle class & 56 & $42.69( \pm 9.03)$ & & \\
\hline & Middle class & 100 & $48.91( \pm 18.96)$ & 7.191 & 0.000 \\
\hline & Lower middle class & 199 & $48.84( \pm 18.04)$ & & \\
\hline & Lower class & 222 & $41.88( \pm 21.31)$ & & \\
\hline 9 & Maximum education in t & & & & \\
\hline & Illiterate & 19 & $42.91( \pm 18.25)$ & & \\
\hline & Upto primary & 68 & $45.58( \pm 18.49)$ & & \\
\hline & Upto junior high school & 82 & $43.24( \pm 19.13)$ & & \\
\hline & Upto high school & 120 & $46.1( \pm 18.27)$ & 0.702 & 0.648 \\
\hline & Upto intermediate & 132 & $46.77( \pm 23.85)$ & & \\
\hline & Upto graduation & 126 & $42.98( \pm 14.17)$ & & \\
\hline & Above graduation & 63 & $45.99( \pm 15.94)$ & & \\
\hline 10 & Main occupation of head & family & & & \\
\hline & Farmer & 78 & $46.79( \pm 15.47)$ & & \\
\hline & Labour & 228 & $45.58( \pm 22.64)$ & & \\
\hline & Service & 137 & $43.23( \pm 16.97)$ & 0.536 & 0.709 \\
\hline & Business & 96 & $45.08( \pm 14.40)$ & & \\
\hline & Skilled worker & 71 & $44.88( \pm 17.19)$ & & \\
\hline
\end{tabular}


Table 5: Fat intake (gm/day) of study subjects according to their socio-demographic characteristics.

\begin{tabular}{|c|c|c|c|c|c|}
\hline Sr. no. & Variables & $\mathbf{N}$ & Mean (SD) & $\mathbf{F}$ & $\mathbf{P}$ \\
\hline 1 & Age of the subjects ( in $y$ & & & & \\
\hline & $15-24$ & 245 & $38.34( \pm 30.98)$ & \multirow{4}{*}{1.735} & \multirow{4}{*}{0.159} \\
\hline & $25-34$ & 170 & $33.14( \pm 28.05)$ & & \\
\hline & $35-44$ & 151 & $40.66( \pm 34.54)$ & & \\
\hline & $\geq 45$ & 44 & $39.15( \pm 30.57)$ & & \\
\hline \multirow[t]{3}{*}{2} & Religion & & & & \\
\hline & Hindu & 566 & $37.56( \pm 31.05)$ & \multirow{2}{*}{0.011} & \multirow{2}{*}{0.917} \\
\hline & Muslim & 44 & $37.05( \pm 32.96)$ & & \\
\hline \multirow[t]{4}{*}{3} & Caste & & & & \\
\hline & SC \& ST & 191 & $32.23( \pm 33.85)$ & \multirow{3}{*}{4.084} & \multirow{3}{*}{0.017} \\
\hline & OBC & 285 & $39.68( \pm 30.83)$ & & \\
\hline & Others & 134 & $40.49( \pm 26.84)$ & & \\
\hline \multirow[t]{4}{*}{4} & Type of family & & & & \\
\hline & Nuclear & 320 & $39.36( \pm 30.52)$ & \multirow{3}{*}{2.356} & \multirow{3}{*}{0.096} \\
\hline & Joint & 260 & $34.54( \pm 31.96)$ & & \\
\hline & Three generation family & 30 & $43.76( \pm 26.11)$ & & \\
\hline \multirow[t]{4}{*}{5} & Marital status of subjects & & & & \\
\hline & Unmarried & 159 & $39.54( \pm 31.15)$ & \multirow{3}{*}{0.468} & \multirow{3}{*}{0.627} \\
\hline & Married & 436 & $36.76( \pm 31.27)$ & & \\
\hline & Widow \& separated & 15 & $38.26( \pm 29.07)$ & & \\
\hline \multirow[t]{8}{*}{6} & Educational status of sub & & & \multirow{8}{*}{0.433} & \\
\hline & Illiterate & 206 & $38.31( \pm 34.82)$ & & \multirow{7}{*}{0.857} \\
\hline & Primary & 70 & $36.04( \pm 31.49)$ & & \\
\hline & Middle & 90 & $34.60( \pm 29.11)$ & & \\
\hline & H. School & 86 & $40.65( \pm 31.07)$ & & \\
\hline & Intermediate & 93 & $36.15( \pm 28.19)$ & & \\
\hline & Graduate & 50 & $37.12( \pm 25.82)$ & & \\
\hline & PG or above & 15 & $43.06( \pm 24.82)$ & & \\
\hline \multirow[t]{7}{*}{7} & Primary occupation of su & & & & \\
\hline & Housewife & 386 & $36.68( \pm 31.13)$ & & \\
\hline & Domestic worker & 36 & $33.09( \pm 28.86)$ & & \\
\hline & Agriculture labor & 19 & $39.82( \pm 32.82)$ & 0527 & 0748 \\
\hline & Service & 11 & $37.61( \pm 27.41)$ & 0.537 & 0.748 \\
\hline & Student & 130 & $40.96( \pm 31.42)$ & & \\
\hline & Skilled worker & 28 & $37.35( \pm 34.56)$ & & \\
\hline 8 & Socio-economic status & & & & \\
\hline & Upper class & 33 & $23.45( \pm 3.84)$ & & \\
\hline & Upper middle class & 56 & $35.23( \pm 9.09)$ & & \\
\hline & Middle class & 100 & $45.66( \pm 32.11)$ & 19.004 & 0.000 \\
\hline & Lower middle class & 199 & $48.79( \pm 31.56)$ & & \\
\hline & Lower class & 222 & $26.43( \pm 31.63)$ & & \\
\hline 9 & Maximum education in th & & & & \\
\hline & Illiterate & 19 & $38.83( \pm 30.38)$ & & \\
\hline & Upto primary & 68 & $37.89( \pm 33.79)$ & & \\
\hline & Upto junior high school & 82 & $36.66( \pm 33.02)$ & & \\
\hline & Upto high school & 120 & $39.39( \pm 32.66)$ & 0.694 & 0.654 \\
\hline & Upto intermediate & 132 & $38.45( \pm 35.28)$ & & \\
\hline & Upto graduation & 126 & $33.05( \pm 24.65)$ & & \\
\hline & Above graduation & 63 & $41.31( \pm 25.39)$ & & \\
\hline 10 & Main occupation of head & family & & & \\
\hline & Farmer & 78 & $39.02( \pm 28.23)$ & & \\
\hline & Labor & 228 & $36.57( \pm 35.77)$ & & \\
\hline & Service & 137 & $37.21( \pm 27.92)$ & 0.156 & 0.960 \\
\hline & Business & 96 & $39.01( \pm 25.51)$ & & \\
\hline & Skilled worker & 71 & $37.54( \pm 31.88)$ & & \\
\hline
\end{tabular}


In comparison to these groups calorie intake was significantly more in subjects belonging to middle class $(1765.57 \pm 442.72 \mathrm{Kcal} /$ day $)$. Calorie intake of lower middle class $(1742.58 \pm 427.16 \mathrm{Kcal} /$ day $)$ was significantly more than upper and lower classes. Post Hoc test also revealed that calorie intake of middle class was significantly more than upper middle class. Calorie intake of subjects having maximum education in the family as illiterate, up to Junior High School and above graduation was $1472.13 \pm 520.62, \quad 1587.73 \pm 532.80 \quad$ and $1595.54 \pm 489.85 \mathrm{Kcal} /$ day, respectively. In other categories energy intake of subjects were more than 1600 Kcal/day. However, there existed no significant association between average calorie intake and maximum education in the family.

Age and socio-economic status of study subjects were found to be significantly $(\mathrm{p}<0.05)$ associated with protein intake (Table 4). The average protein intake in 15-24 years age group was $46.1 \pm 17.53 \mathrm{gm} /$ day. Corresponding value for 25-34 years, 35-44 years and $\geq 45$ years age groups were $41.4 \pm 15.93 \mathrm{gm} / \mathrm{day}, 47.1 \pm 23.33 \mathrm{gm} / \mathrm{day}$ and $46.42 \pm 16.91 \mathrm{gm} /$ day, respectively. The post-hoc test revealed that in comparison to 15-24 years and 35-44 years age group subjects' daily protein intake of 25-34 years age group was found to be significantly $(\mathrm{p}<0.05)$ less.

The average daily intake of protein (gm/day) for upper class was found to be $35.72 \pm 4.06$ and corresponding value for upper middle class, middle class, lower middle class and lower class were 42.69 $\pm 9.03,48.91 \pm 18.96$, $48.84 \pm 18.04$ and $41.88 \pm 21.31$, respectively. The post hoc test revealed that in comparison to upper and upper middle and lower class, protein intake of middle and lower middle classes were significantly $(\mathrm{p}<0.05)$ more; in comparison to middle class and lower middle class protein intake of lower class was $(p<0.05)$ less. There was no significant $(\mathrm{p}>0.05)$ difference in protein intake of subjects from upper, upper middle and lower classes.

The other insignificant variables for protein intake were religion, type of family, marital status, educational status and primary occupation of subjects, maximum education in the family and main occupation of head of the family.

Except caste and SES no other socio-demographic characteristics of study subjects were significantly $(\mathrm{p}<0.05)$ associated with daily fat intake ( $\mathrm{gm} / \mathrm{day})$. The lowest average fat intake was found to be in Scheduled Caste (SC) \& Scheduled Tribes (ST) caste category $(32.23 \pm 33.85 \mathrm{gm} /$ day $)$. For subjects belonging to other backward class (OBC) and others castes the average values were $39.68 \pm 30.83 \mathrm{gm} /$ day and $40.49 \pm 26.84$ $\mathrm{gm} /$ day, respectively (Table 5). The post hoc test revealed that in comparison to SC \& ST category fat intake was significantly $(\mathrm{p}<0.05)$ more in OBC and other castes. Fat intake was similar in $\mathrm{OBC}$ and other caste categories.
The average fat intake among subjects belonging to upper and upper middle class were $23.45 \pm 3.84$ and $35.23 \pm 9.09$ $\mathrm{gm} /$ day, respectively; corresponding values for middle, lower middle and lower classes were 45.66 \pm 32.11 , $48.79 \pm 31.56$ and $26.43 \pm 31.63 \mathrm{gm} /$ day, respectively. The post hoc test revealed that in comparison to upper and upper middle class as well as lower class daily fat intake was significantly $(\mathrm{p}<0.01)$ more in subjects belonging to middle and lower middle classes. In comparison to upper middle and lower middle classes, fat intake of subjects from lower class was found to be significantly $(p<0.05)$ less. In comparison to upper class with upper middle and lower classes, and middle class with lower middle class, there existed no significant $(\mathrm{p}>0.05)$ difference in daily fat intake of subjects.

\section{DISCUSSION}

The constitution of India as well as preamble of World Health Organization (WHO), emphasized on raising health and nutritional status of women of reproductive age group. A normal healthy women gains about $12 \mathrm{~kg}$ during pregnancy but poor rural Indian women on an average gain $6.5 \mathrm{kgs}$ only so under nutritional stress coupled with lactation, leads to chronic under nutrition of mother and child both. A considerable proportion of women of Uttar Pradesh state have a body mass index (BMI) less than $18.5 \mathrm{~kg} / \mathrm{m}^{2}$ indicating high prevalence of nutritional deficiency. Mainly low BMI women are found in rural areas, among uneducated women and scheduled caste and scheduled tribes group and in the families with low standard of living index. ${ }^{4}$ Indian women were disadvantage socially, educationally and economically and were excluded from Indian society until the government recognized the groups formally in the 1930s.

In comparison to the findings of the present study, lower intake of energy and protein have been reported in a study conducted on non-pregnant and non-lactating (NPNL) rural women of reproductive age group (18-40 years). They reported energy intake to be $52-53 \%$ of RDA which is lower than the figure of $84.4 \%$ by subjects of present study. ${ }^{10}$ In an another study by Mittal ${ }^{11}$ the mean energy and protein intake was found to be 983.60 $( \pm 309.6) \mathrm{kcal} /$ day and $27.33( \pm 8.2) \mathrm{gm} /$ day, respectively which met only $50 \%$ of the nutrient requirements.

The National Nutrition Monitoring Bureau (NNMB) surveys of India provided data on time trends in dietary intake by 24 hours dietary recall and nutritional status of the population in eight states from 1975 to 2005 . NNMB surveys indicated that there had been reduction in energy and protein intake except among the poor; over all there had been a small decrease in total energy and protein intake in both urban and rural areas. However, the average energy $(1834 \pm 485 \mathrm{kcal})$ and protein intakes $(49.4 \pm 16 \mathrm{gm})$ of subjects were more than the present study. $^{12}$ 
In present study socioeconomic status exerted significant influence on calorie consumption of study subjects; this was maximum in middle class in comparison to lower middle and lower classes. In comparison to present study average energy intake has been observed more in subjects of a Brazilian study. The results of the latter study showed that in comparison with the lowest quartile of income, individuals with special reference to females in the highest income quartile had greater mean intakes of energy, added sugar, alcohol, animal protein, total fat, saturated fat, monounsaturated fat and Trans fat. ${ }^{13}$

It is possible that in a community where women of reproductive age group are having less macro nutrient intake, the similar picture may prevail for adolescent girls as well. This is substantiated by a study conducted on rural adolescent girls of Varanasi district which revealed that more than two third adolescent girls had inadequate intake of calorie, protein and fat and average intakes of macro and micronutrients (except vitamin A) in comparison to RDA. ${ }^{14}$

In a cross sectional study on dietary intake and rural urban migration in India, it was found that median energy intake in the rural, migrant and urban women groups was 2153, 2504, and $2644 \mathrm{kcal} /$ day, respectively. Differences between these groups in proportion of energy from macronutrients were small but migrant and urban women had a higher proportion of energy from fat, and protein than rural women, and a lower proportion from carbohydrates. Migrant women had similar proportions of energy from saturated fat as rural women. ${ }^{15}$ In spite that measuring parameter were different, it appears that macro nutrient intake have been more than the observed value in present study.

Another study on women and nutrition in Himalayan region revealed that the average energy intake per capita per day was found to be $1942.2 \mathrm{kcal}$, which was $21.78 \%$ below the standard requirement. ${ }^{16}$ The average per capita, per day protein intake was found to be 49.25 grams which was $20.56 \%$ below the standard requirement of 62 grams. The average fat intake per capita per day was found to be 29.81 grams which was $6.84 \%$ below the standard requirement of 32 grams. In comparison to the present study calorie and protein intakes were more in subjects of Himalayan region whereas fat intake was low.

An African study on dietary intakes and body mass indices of NPNL women from the coastal and guinea savannah zones of Ghana showed that significantly more women in the Guinea Savannah zone did not meet their Estimated Average Requirements (EAR) for protein $(81 \%)$, compared to women in the Coastal zone $(44 \%) .{ }^{17}$

Apart from these findings castes and age of the rural women had significant influence on energy intake. A study on rural women in Azamgarh district of Uttar Pradesh revealed that one third of upper caste females had energy intake less than $80 \%$ of the required level while as high as $80 \%$ females of SC/ST belonged to this category and in the community, around half of the females consumed only that much amount of food which was not sufficient to put them even in the category of energy intake equivalent to $80 \%$ of the energy expenditure. $^{18}$

Adverse dietary situation prevailing during adolescence exerts significant influence on nutritional status of women of reproductive age group. A study from rural setting of Varanasi district on macro nutrient intake of adolescent girls ${ }^{19}$ showed that average calorie consumption in age groups 15-17 and 18-19 years were 1690.9 \pm 488.6 , and $1648.1 \pm 366.2 \mathrm{kcal} / \mathrm{day}$, respectively. In case of $7.8 \%$ and $4.4 \%$ subjects belonging to age groups 15-17 and 18-19 years and in all, 9.5\% subjects had calorie consumption $<50 \%$ of RDA. There existed significant association between calorie consumption and age of the subjects.

In contrast to the findings of present study, average energy intake of subjects in the study of Walia ${ }^{20}$ has been observed to increase with increase in age. In the age group 30-35 years, females on an average consumed $2098.6 \mathrm{kcal} /$ day in their daily diet that increased to 2238 $\mathrm{kcal}$ in the age group 45-50 years, this demonstrated an increase of $6.67 \%$. Administration of ANOVA tests to the daily dietary energy intake data of different groups revealed the existence of significant differences between the various age groups. Further exploration with the Schaeffe post Hoc test recognized significantly greater intake of daily dietary energy intake values by females belonging to the higher groups as compared to the lower age groups.

Present study showed a significant $(\mathrm{p}<0.05)$ association between age and socio-economic status of study subjects with their protein intake. The results showed an increase of protein intake among subjects with the increase of their age (except in subjects of 25-34 years) and in comparison to subjects belonging to middle class and lower middle class protein intake of lower class was $(\mathrm{p}<0.05)$ less. In an another study on adolescent girls of rural Varanasi the average protein intake was $28.2 \pm 22.4$ gm/day for $15-17$ years age group and $26 \pm 21 \mathrm{gm} /$ day for 18-19 years age group. Except this there also existed a significant $(\mathrm{p}<0.01)$ difference in caste wise protein intake of study subjects; $22 \%$ SC, $7.5 \%$ OBC and $12.7 \%$ others caste category subjects had protein intake $<50 \%$ of RDA. ${ }^{19}$ In a study on Indian girls belonging to deprived and disadvantaged communities, a lower energy (1460.5 Kcal) and protein (30.6 gm) intake was found. ${ }^{21}$

Fat intake among the subjects of the present study showed a significant $(\mathrm{p}<0.05)$ association with caste and SES. The lowest average fat intake was found to be in SC \& ST caste category and almost similar daily fat intake was found to be in subjects belonging to OBC and other caste categories. Along with the castes, fat intake of study 
subjects was found to be less in subjects belonging to lower SES.

According to Nagamani in her study on nutritional status of rural young women the majority of rural young women are not only undernourished but also short stature and emaciated. ${ }^{22}$ Results demonstrated that the diets of rural forward class women is relatively better than the rural scheduled class women but the intakes of all women were poor when compared to RDA, both the groups of young women met only 40 to 50 percent of RDA.

In an another study on nutritional vulnerability of women and children in Sahariya tribal community of Madhya Pradesh, India the observed calorie, fat, vitamin A, riboflavin, vitamin $\mathrm{C}$ and folic acid intake among women was lower than recommended dietary allowances. The mean energy intake of Sahariya women (15-49 years) was $1478 \mathrm{kcal}$ which was $33.8 \%$ deficit and the mean fat intake was $12.9 \mathrm{~g}$ which was $26.3 \%$ deficit with respect to RDA. ${ }^{23}$

Some other findings pertaining to adolescent girls from rural Varanasi showed that in case of $20 \%$ subjects fat consumption was $<50 \%$ of RDA. In age group of $15-17$ years $15.6 \%$ subjects had fat consumption below $<50 \%$ of RDA, whereas this was $12.1 \%$ in age group of $18-19$ years; $22.1 \%$ subjects going to school and $11.5 \%$ subjects who left school had fat consumption $<50 \%$ of RDA. Fat consumption $<50 \%$ was maximum in students $(22.1 \%$ ) followed by subjects engaged in domestic (8.7\%) and other work $(13 \%)$. There existed significant association between fat consumption and age, literacy and main occupation of study subjects. ${ }^{19}$

\section{CONCLUSION}

In spite of the fact that average macro nutrient intakes are less than the estimated RDAs, there is considerable proportion of subjects occupying extreme positions on the scale of macro nutrient intake and therefore targeted nutrition education programmes are desired in this area to combat problems of under and over nutrition in the women of reproductive age group.

There had been wide variation in the intake of macro nutrient by women of reproductive age group of the study area. This calls for targeted nutrition education initiatives to reduce the problem of mal nutrition in this age group.

\section{ACKNOWLEDGEMENTS}

Authors duly express their thanks to the participants of this study without whose co-operation this study would never been possible.

\footnotetext{
Funding: No funding sources Conflict of interest: None declared

Ethical approval: The study was approved by the Academic Bodies of Banaras Hindu University
}

\section{REFERENCES}

1. Mishra CP, Khanam Z. Food Security: Challenges and options. Indian J prev Soc Med. 2010;41(34):127-37.

2. Vyas A. The views paper (The voice of youth). Business. 2008.

3. International Institute of Population Sciences, ORC Marco, Ministry of Health and Family Welfare, India. National Family Health Survey. (NFHS-2). 1998-99. Accessed 30 Nov, 2015. http://rchiips.org/ nfhs/india2.shtml.

4. International Institute of Population Sciences. ORC Marco, Ministry of Health and Family Welfare, India. National Family Health Survey (NFHS-3). 2005-06. Accessed 30 Nov, 2015. http://rchiips.org/ nfhs/pdf/India.pdf.

5. Gupt MC, Mahajan BK. Text Book of Preventive and Social Medicine. 3rd edition. India: Jaypee Brothers Medical Publishers. 2003:486-487.

6. National Human Development Report, India. 2001;1-24.

7. Census of India. Office of Registrar General. 2011. http://www.censusindia.net Accessed 30 Nov, 2015.

8. Khanam Z, Mishra CP, Shankar H. Validity of Body Mass Index for predicting Over Weight and Obesity in Indian Rural Women. International Journal of Food and Nutritional Sciences. 2013;2(3):107-112.

9. Gopalan C, Ramasastri BV, Balasubramaniam SC. Nutritive Value of Indian Food. NIN, ICMR, Hyderabad. 1995;1-156.

10. Mittal PC, Srivastava S. Nutritional Status and Food related Traditions of Oraon Tribes of New Mal, West Bengal, 2006. www.ncbi.nlm.nih.gov/ pubmed/16602836. Accessed 30 Nov, 2015.

11. Mittal M. To assess the Nutritional Status and Morbidity pattern among Non-pregnant and nonLactating rural women of Reproductive age group (18-40 years). International Journal of Scientific and Research Publications. 2013;3(9):1-47.

12. National Nutrition Monitoring Bureau. Technical Report No: 24. 2006;1-166.

13. Souza RAG, Yokoo EM, Sichieri R, Pereira RA. Energy and macronutrient intakes in Brazil: results of the first nationwide individual dietary survey. 2015;18(17):3086-95.

14. Choudhary S, Mishra CP, Shukla KP. Dietary Pattern and Nutrition related Knowledge of Rural Adolescent Girls. Indian J Prev Soc Med. 2010;41(3-4):207-15.

15. Bowen L, Shah E, De Stavola B, Ness A, Kinra S, Bharathi AV. Dietary Intake and Rural-Urban Migration in India: A Cross-Sectional Study. PLoS ONE. 2011;6(6):1-8.

16. Pant BR. Women and Nutrition in Himalayan Region: A Case Study. 2001. UGC, New Delhi: http://gbpihedenvis.nic.in/html/vol16_1/B.R.\%20Pa nt.htm Accessed 24 Feb, 2014.

17. Kobati GY, Lartey A, Marquis GS, Colecraft EK, Butler LM. Dietary Intakes and Body Mass Indices 
of Non-Pregnant, Non-Lactating (NPNL) Women from the Coastal and Guinea Savannah Zones of Ghana. African Journal of Food, Agriculture, Nutrition and Development. 2012;12(1):5843-61.

18. Mishra CP, Yadav S, Srivastava P. Energy Balance vis-à-vis Nutritional Status of Rural Reproductive Age Group Females of Azamgarh District, Uttar Pradesh. Indian J Prev Soc Med. 2011;42(3):329-34.

19. Krishna J, Gupta MK, Mishra CP. Macro nutrient intake status of adolescent girls in a rural area of Varanasi district. Indian $\mathbf{J}$ Prev Soc Med. 2014;45(3-4):223-34.

20. Walia M. Energy Intake and Energy Expenditure Pattern in Middle Aged Females 30-50 Years of Age Living in Urban Slums of Punjab. Journal of Exercise Science and Physiotherapy. 2007;3(2):1716.

21. Nagamani G. Clinical Nutritional Status of Indian Girls in Deprived and Disadvantaged Communities: A Special Reference to Select Macro and Micro
Nutrients. Global Journal for Research Analysis. 2014;3(2):60-1.

22. Nagamani G. Nutritional Status of Rural Young Women-A Profile. Indian Journal for Research. 2014;3(2):132-4.

23. Ghosh-Jerath S, Singh A, Bhattacharya A, Ray S, Yunus S, Zodpey SP. Dimensions of Nutritional Vulnerability: Assessment of Women and Children in Sahariya Tribal Community of Madhya Pradesh in India. Indian Journal of Public Health. 2015;57(4):261-7.

Cite this article as: Khanam Z, Shankar H, Mishra CP. Macro-nutrient intake of reproductive age group women: findings of a community based study from rural Varanasi. Int J Community Med Public Health 2016;3:566-75. 